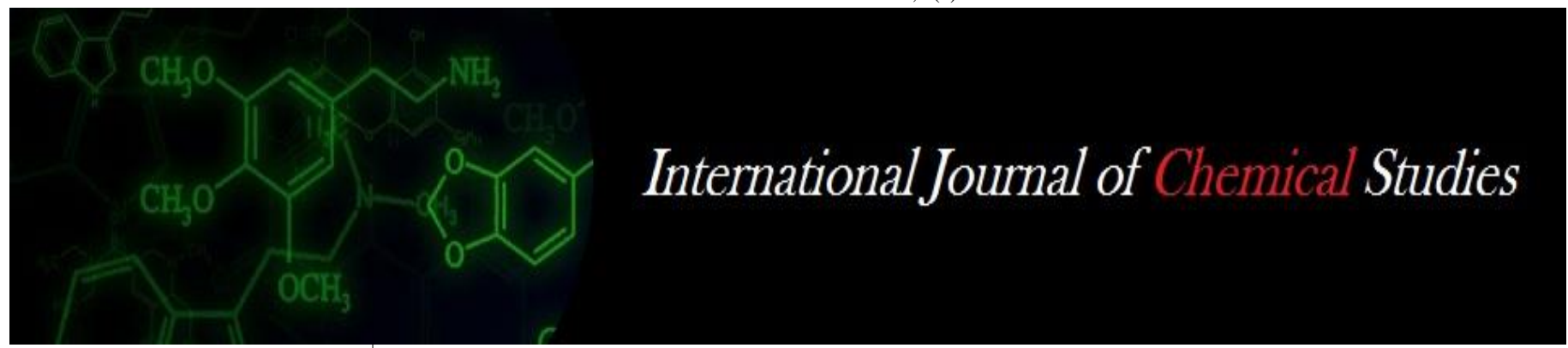

P-ISSN: 2349-8528

E-ISSN: 2321-4902

www.chemijournal.com

IJCS 2020; 8(4): 2067-2070

(C) 2020 IJCS

Received: 28-05-2020

Accepted: 30-06-2020

\section{KG Kandarkar}

Department of Agricultural Botany, PGI, MPKV, Rahuri, Maharashtra, India

\section{NS Kute}

Principal scientist, Pulses Improvement Project, MPKV,

Rahuri, Maharashtra, India

\section{AU Ingle}

Ph. D. Scholar, Department of Agricultural Botany, PGI, MPKV, Rahuri, Maharashtra, India

\section{GC Shinde}

Assistant Professor, Department of Agricultural Botany, PGI, MPKV, Rahuri, Maharashtra, India

Corresponding Author:

KG Kandarkar

Department of Agricultural

Botany, PGI, MPKV, Rahuri,

Maharashtra, India

\section{Genetic divergence studies in Pigeonpea [Cajanus cajan L. Millsp.]}

\author{
KG Kandarkar, NS Kute, AU Ingle and GC Shinde
}

DOI: https://doi.org/10.22271/chemi.2020.v8.i4v.9934

\begin{abstract}
From the results of Mahalanobis's $\mathrm{D}^{2}$ statistics it is revealed that the twenty-seven genotypes were grouped into six clusters. In the present investigation, $\mathrm{D}^{2}$ values between all possible pairs of twentyseven genotypes ranged from 50.41 (cluster IV) and (cluster VI) to 825.41 (cluster III) and (cluster VI). Cluster II had maximum genotypes (10 genotypes) followed by, cluster I ( 8 genotypes), and cluster III (6 genotypes) and remaining all other clusters viz., IV, V and VI were solitary cluster since they had only single genotype. The distribution pattern of genotypes into different clusters revealed no parallelism between genetic and geographic diversity. The maximum inter cluster distance was found between cluster III and VI $\left(\mathrm{D}^{2}=825.41\right)$, followed by cluster V and III $\left(\mathrm{D}^{2}=760.65\right)$ and cluster III and IV $\left(\mathrm{D}^{2}\right.$ $=578.9$ ) which indicated that hybridization between parents selected from these clusters may create in maximum variability. Cluster-IV rendered highest cluster mean values for the characters viz., number of branches per plant (29.40), number of pods per plant (232.33), Plant spread (29.40) and 100 seed wt. (g) (11.79). Among all the traits, the contribution of contribution of various characters towards the expression of genetic divergence were days to $50 \%$ flowering ( 71.51 per cent), days to maturity ( 9.40 per cent), plant spread (7.69 per cent), number of branches per plant (3.99 per cent) and 100 seed weight ( 2.85 per cent) together contributed for about 95.44 per cent of the total divergence. Therefore, these traits should be emphasized during the selection.
\end{abstract}

Keywords: Pigeonpea, genetic divergence, $\mathrm{D}^{2}$ statistics

\section{Introduction}

Pigeonpea (Cajanus cajan L. Millsp.) is an important grain legume crop of rainfed agriculture in the semi-arid tropics. It plays an important role in food security, balanced diet and alleviation of poverty because of its diverse usages as a food, fodder and fuel (Rao et al. 2002). It is a protein rich (20-23\%), versatile crop and thus an important source of income for smallholder farmers. Along with that, it helps to increase soil fertility by fixing atmospheric nitrogen. Pigeonpea is the second most important pulse crop next to chickpea in India. Out of total production of pulse (239.5 lakh tones), 16.78 per cent share (40.2 lakh tonnes) is from pigeonpea (Directorate of Economics and Statistics, 2017 a 2nd advance estimate). In Maharashtra pigeonpea cultivated over an area of 12.29 lakh ha with a production of 9.84 lakh tones and productivity of $800 \mathrm{~kg} / \mathrm{ha}$ (2nd estimates Project Coordinator Pigeonpea annual report 2017 b). Maharashtra ranks first both in respect of area production (11.19 lakh ha and 8.88 lakh tones) which contribute to $29.11 \%$ and $29.68 \%$ of total pigeonpea area and production in India followed by Karnataka (7.37 lakh ha and 4.78lakh tones) respectively (Directorate of Economics and Statistics, 2016-17).

Success of yield improvement largely depends upon the magnitude and nature of genetic variability present in the existing material. It is the pre-requisite for the progress of plant breeding programme. Moreover, estimation of genetic diversity among genotypes through Mahalanobis $\mathrm{D}^{2}$ technique is a very useful to selection of diverse parents. The conventional breeding procedures such as single plant selection from locally adapted cultivars and pedigree selection from inter-varietal crosses have remained main methods of improvement for higher yield with resistance to major disease, large seed size and reduced maturity (Saxena and Sultana, 2010) ${ }^{[9]}$, even though the success observed in increasing yields levels as been rather small. For an outstanding breeding programme in the crop improvement, diversity analysis greatly helps the breeder in the identification and proper choice of parents for specific breeding objectives. Keeping in a view all these aspects, the present study was carried out to study 
genetic divergence among different pigeonpea genotypes and their potential utilization in future hybridization or crop improvement programme.

\section{Materials and Method}

The experiment was conducted in Randomized Block Design (RBD) with three replications. Each genotype consisted of four rows with plant to plant distance of $25 \mathrm{~cm}$. The rows were spaced $90 \mathrm{~cm}$ apart. The experiment was sown in Kharif 2017 at Pulses Improvement Project, MPKV, Rahuri. Recommended package of practices were followed to raise good crop. Observations on metric traits were recorded on single plant basis from five randomly selected competitive plants from each genotype in each replication separately. Observations on flowering and maturity were recorded on plot basis. Total nine characters were studied which are days to 50 $\%$ flowering, days to maturity, plant height $(\mathrm{cm})$, plant spread (cm), number of branches per plant, number of pods per plant, number of seeds per pod, 100 seed weight $(\mathrm{g})$ and Seed yield (kg per ha). The analysis of divergence was carried out by $\mathrm{D}^{2}$ statistic of Mahalanobis (1936) [4] and Tocher's method followed for cluster formation as described by Rao (1952) ${ }^{[6]}$. All statistical analysis was carried with help of INDOSTATStatistical software.

\section{Result and Discussion}

Mahalanobis's $\mathrm{D}^{2}$ statistic was computed between all possible pairs of twenty-seven pigeonpea genotypes and the genetic diversity present among the genotypes was assessed.

\section{Distribution of genotypes into clusters}

Twenty-seven genotypes of pigeonpea were grouped into six clusters by Tocher's method. The grouping of clusters is given in Table1. The results indicated that a ten number of diverse genotypes appeared in cluster II followed by 8 genotypes cluster I and 6 genotypes each in cluster III whereas single genotype present in cluster IV, V and VI.

The intra and inter cluster distances (D) between all possible pairs of three clusters were computed and presented in Table2. A study of the data revealed that the inter-cluster distance (D) ranged from 28.73 to 7.10 . The maximum inters - cluster distance $(\mathrm{D}=28.17)$ was observed between cluster III and VI followed by those between cluster III and V (D= $27.58)$, between cluster III and IV ( $\mathrm{D}=24.06)$, between cluster II and III $(\mathrm{D}=20.22)$, between cluster I and cluster V $(\mathrm{D}=17.88)$ and between cluster I and cluster VI $(\mathrm{D}=17.18)$. The minimum intercluster distance $(D=8.13)$ was observed between cluster IV and II followed by between cluster I and cluster II $(\mathrm{D}=10.05)$, between cluster II and VI $(\mathrm{D}=10.64)$, between cluster II and cluster V $(\mathrm{D}=11.25)$, between cluster I and cluster IV $(\mathrm{D}=12.73)$ and between cluster I and cluster II $(\mathrm{D}=13.2)$.

Intra-cluster distance (D) ranged from 0 to 6.81. At intracluster level, cluster-II had the highest value $(\mathrm{D}=6.81)$, followed by cluster III $(\mathrm{D}=6.41)$ and cluster I $(\mathrm{D}=5.44)$. The minimum intra-cluster distance $(\mathrm{D}=0)$ were observed in cluster-IV, cluster V and cluster VI each of which included single genotypes. These results were in agreement with the earlier findings of Pandey et al. (2013) ${ }^{[5]}$

\section{Contribution of various characters towards genetic divergence}

The estimates contribution of various characters towards the expression of genetic divergence were days to $50 \%$ flowering (71.51 per cent), days to maturity (9.40 per cent), plant spread (7.69 per cent), number of branches per plant (3.99 per cent), 100 seed weight (2.85 per cent), yield $\mathrm{kg}$ per ha $(2.28$ per cent), number of pods per plant (1.14per cent) plant height ( 0.57 per cent) and number of seeds per pod ( 0.57 per cent $)$. Those accounted nearly 100 per cent of total divergence in the material (Table3). Among all the traits, the contribution of contribution of various characters towards the expression of genetic divergence were days to $50 \%$ flowering (71.51 per cent), days to maturity ( 9.40 per cent), lant spread ( 7.69 per cent), number of branches per plant (3.99 per cent) and 100 seed weight (2.85 per cent) together contributed for about 95.44 per cent of the total divergence. Therefore these traits to be emphasized during selection. The similar findings were also reported by Singh et al. (2010) ${ }^{[10]}$ and Rao et al. (2013) [7].

\section{Cluster means for different characters}

Cluster mean for all the nine characters are presented in Table 4. The results clearly indicated appreciable difference among cluster means for most of the characters. Among all clusters Cluster-IV rendered highest cluster mean values for the characters viz., number of branches per plant (29.40), number of pods per plant (232.33), Plant spread (29.40) and 100 seed wt. (gm) (11.79). However, highest cluster mean for days to $50 \%$ flowering (145.67 days), plant height $(299.93 \mathrm{~cm})$ and yield $\mathrm{kg}$ per ha (2700) reported in cluster VI; for days to maturity (196.67) in cluster V and for seeds per pod (3.95) in cluster I. This results indicating the importance of selection of genotypes from the corresponding clusters in hybridization programmes for affecting improvement in the respective traits.

While, lowest cluster mean for days to 50\% flowering (99.61 days) and days to maturity (171.67days) were reported in cluster III; for plant height $(254.84 \mathrm{~cm})$ in cluster IV; for plant spread $(79.17 \mathrm{~cm})$, number of branches per plant (14.67), number of seeds per pod (2.87) and yield $\mathrm{kg}$ per ha (737) in cluster V; for 100 seed weight $(10.60 \mathrm{gm})$ in cluster II. In present investigation results revealed that there is no single cluster with all desirable traits where selection could be effective. Hence, judicial cross combination should be adopted to obtain effective improvement for targeted traits. These results were in line with Reddy et al. (2015) ${ }^{[8]}$.

Table 1: Distribution of 27 genotypes of Pigeon pea into different clusters

\begin{tabular}{|c|c|c|}
\hline $\begin{array}{c}\text { Cluster } \\
\text { No. }\end{array}$ & $\begin{array}{c}\text { No of genotypes } \\
\text { included }\end{array}$ & Genotypes \\
\hline I & 8 & BDN 2,JKM 189,CRG 2015-007,PT 0723-1-2-3, GJP1601,RVSA 15-8,IPA 17B-11,IPA 17B-10 \\
\hline II & 10 & ICPL 87119, LRG 208, IBTDRG-3, RKPV 455-02,BDN 2014-2,WRG 303,NPMK 15-02,VRG \\
08-004,GJP 1606, SKNP 1416
\end{tabular}


Table 2: Average intra and inter cluster $\mathrm{D}^{2}$ value of 6 clusters from 27 genotypes of Pigeon pea

\begin{tabular}{|c|c|c|c|c|c|c|}
\hline Cluster & I & II & III & IV & V & VI \\
\hline I & $29.59(5.44)$ & $101.002(10.05)$ & $174.24(13.20)$ & $162.05(12.73)$ & $319.7(17.88)$ & $295.15(17.18)$ \\
\hline II & & $46.34(6.81)$ & $408.84(20.22)$ & $66.1(8.13)$ & $126.56(11.25)$ & $113.2(10.64)$ \\
\hline III & & & $41.09(6.41)$ & $578.9(24.06)$ & $760.65(27.58)$ & $825.41(28.73)$ \\
\hline IV & & & & $0.00(0.00)$ & $124.32(11.15)$ & $50.41(7.10)$ \\
\hline V & & & & & $0.00(0.00)$ & $116.2(10.78)$ \\
\hline VI & & & & & & 0.00 \\
& & & & & & $(0.00)$ \\
\hline
\end{tabular}

Table 3: Relative per cent contribution of 9 characters towards total genetic divergence in Pigeon pea

\begin{tabular}{|c|c|c|c|}
\hline Sr. No. & Characters & No. of times appeared first in ranking & Per cent contribution (\%) \\
\hline 1 & Days to 50\% flowering & 251 & 71.51 \\
\hline 2 & Days to maturity & 33 & 9.40 \\
\hline 3 & Plant height (cm) & 2 & 0.57 \\
\hline 4 & Plant spread (cm) & 27 & 7.69 \\
\hline 5 & No. of Branches /plant & 14 & 3.99 \\
\hline 6 & No. of pod/plant & 4 & 1.14 \\
\hline 7 & No. of seeds /pod & 2 & 0.57 \\
\hline 8 & 100 seed wt (gm) & 10 & 2.85 \\
\hline 9 & Yield kg/ha & 8 & 2.28 \\
\hline
\end{tabular}

Table 4: Cluster mean performance for 9 characters in 27 genotypes of Pigeon pea

\begin{tabular}{|c|c|c|c|c|c|c|c|c|c|}
\hline Characters & $\begin{array}{c}\text { Days to } \\
\mathbf{5 0 \%} \\
\text { flowering }\end{array}$ & $\begin{array}{c}\text { Days to } \\
\text { maturity }\end{array}$ & $\begin{array}{c}\text { Plant } \\
\text { height } \\
(\mathbf{c m})\end{array}$ & $\begin{array}{c}\text { Plant } \\
\text { spread } \\
(\mathbf{c m})\end{array}$ & $\begin{array}{c}\text { No. } \\
\text { branches / } \\
\text { plant }\end{array}$ & $\begin{array}{c}\text { No. } \\
\text { pods/ } \\
\text { Plant }\end{array}$ & $\begin{array}{c}\text { No. } \\
\text { seeds / } \\
\text { pod }\end{array}$ & $\begin{array}{c}\text { 100 } \\
\text { seed wt. } \\
\text { (gm) }\end{array}$ & $\begin{array}{c}\text { Yield } \\
\text { (kg/ha) }\end{array}$ \\
\hline Clusters & $\mathbf{1}$ & $\mathbf{2}$ & $\mathbf{3}$ & $\mathbf{4}$ & $\mathbf{5}$ & $\mathbf{6}$ & $\mathbf{7}$ & 8 & 9 \\
\hline I & 119.13 & 177.88 & 282.46 & 124.41 & 21.58 & 200.12 & 3.95 & 11.25 & 2352.74 \\
\hline II & 129.80 & 183.60 & 274.52 & 100.43 & 20.48 & 186.47 & 3.81 & 10.60 & 2080.96 \\
\hline III & 99.61 & 171.61 & 266.91 & 100.83 & 19.38 & 168.39 & 3.81 & 10.83 & 2117.30 \\
\hline IV & 135.33 & 191.67 & 254.87 & 128.43 & 29.40 & 232.33 & 3.88 & 11.79 & 2617.34 \\
\hline V & 136.33 & 196.67 & 276.87 & 79.17 & 14.67 & 110.67 & 2.87 & 11.63 & 737.05 \\
\hline VI & 145.67 & 186.67 & 299.93 & 108.33 & 24.90 & 223.00 & 3.84 & 10.86 & 2700.00 \\
\hline Cluster average & 127.65 & 184.68 & 275.93 & 106.93 & 21.74 & 186.83 & 3.69 & 11.16 & 2100.90 \\
\hline
\end{tabular}

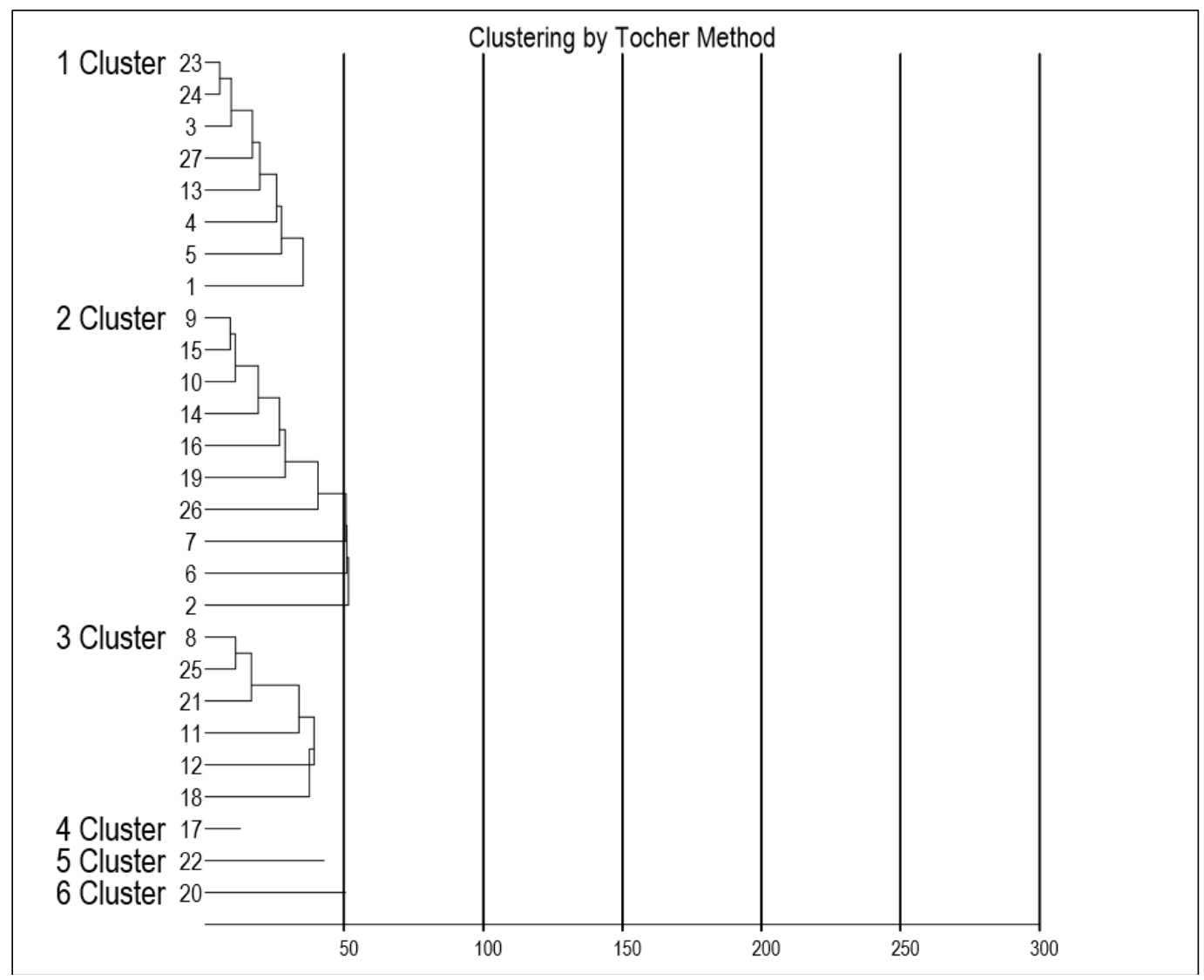

Fig 1: Clustering of pigeonpea genotypes according to their divergence by Toucher's method 


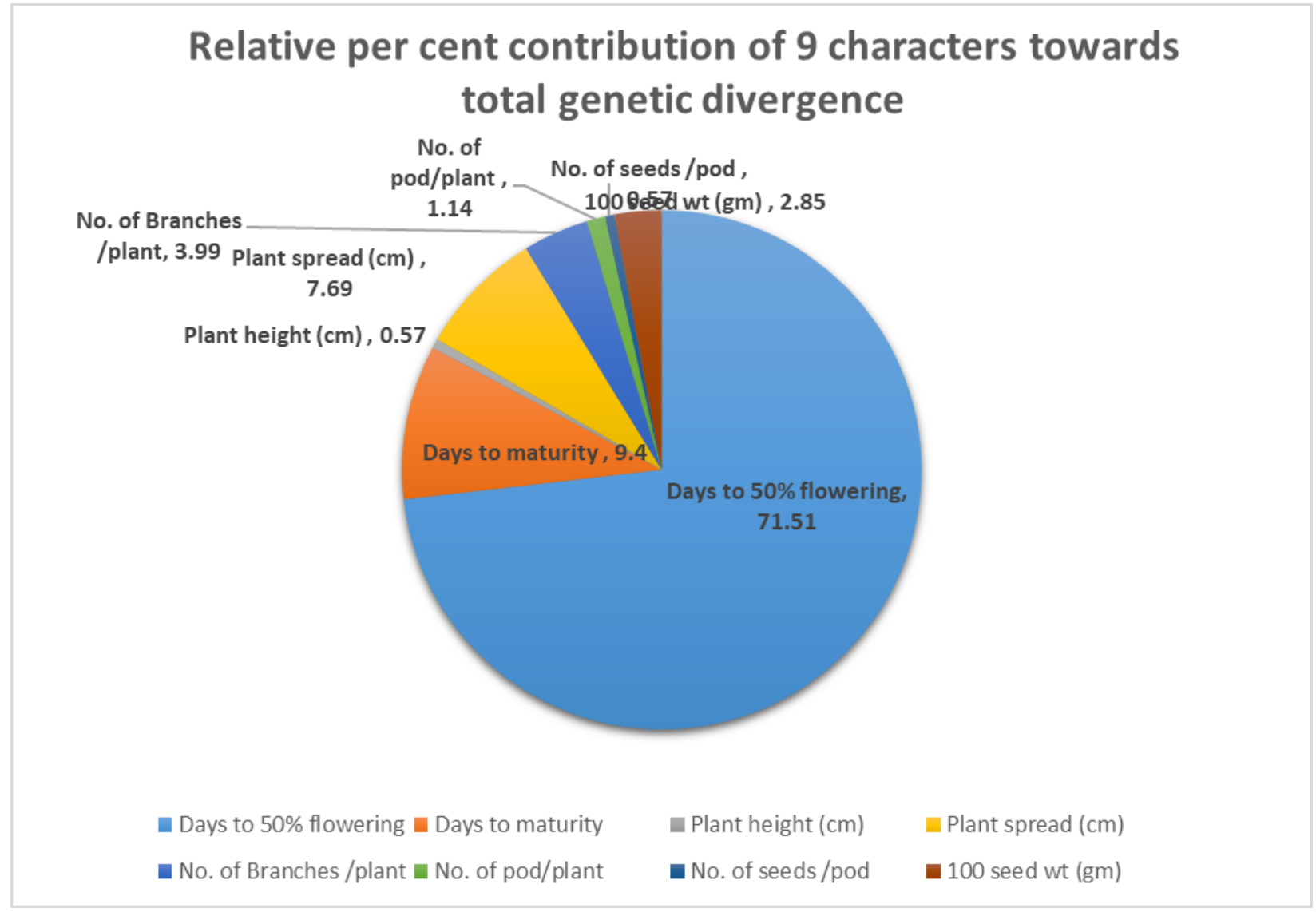

Fig 2: Relative per cent contribution of 9 characters towards total genetic divergence in 27 genotypes of Pigeonpea

\section{Conclusion}

Mahalanobis's D2 statistics helps to reveal genetic divergence within 27 pigeonpea genotypes and which were grouped into six clusters by Tocher's method. On the basis of divergence classes (DC) crosses of genotypes from different clusters can be formulated for next programme and this was grouped on that crosses diversity present between different clusters and separated by moderate genetic distance would give yield with heterotic effect of F1 and transgressive segregants in advance generation. From the results, it could be concluded that intercrossing genotypes from different clusters might results in wide array of variability for exercising effective selection. The genotypes with desirable attributes from corresponding cluster could be further evaluated for isolating high yielding and early maturing genotypes employing mass selection and pedigree selection.

\section{Acknowledgements}

This is part of research work of M.Sc. thesis carried out by Kuldeep Kandarkar and submitted to Mahtma Phule Krishi Vidyapeeth, Rahuri. The authors grateful to the Department of Agricultural Botany and Pulses Improvement Project, MPKV, Rahuri (MS) for the facilities provided and supply of seed material of Pigeonpea genotypes for present study.

\section{References}

1. Akande SR. Multivariate analysis of the genetic diversity of pigeon pea germplasm from South-West Nigeria Journal: Food. Agril. Environ. JFAE. 2007; 5(1):224-227.

2. Anonymous. 2nd Advance estimate for Area, Production and Productivity of pulses and pigeonpea crop. Agricultural Statistics Division, Directorate of Economics and Ministry of Agriculture and Farmers Welfare, Govt. of India, 2017a.
3. Anonymous. 2nd Advance estimates Project Coordinator Pigeonpea annual report. ICAR-Indian Institute of Pulse Research, Kanpur, India. 2017b, 2-4.

4. Mahalanobis's PC. On the generalized distance in statistics. Proc. National Institute of Science, (India). 1936; 2:49-55.

5. Pandey P, Kumar R, Pandey VR, Tripathi M. Genetic divergence in pigeonpea. American Journal of Plant Sciences. 2013; 4:2126-2130.

6. Rao CR. Advanced statistical methods in biometrics research, New York: John Wiley \& Sons, 1952.

7. Rao PJ, Upender M, Bhaskar AV. Variability and genetic diversity in redgram [Cajanus cajan (L.) millsp.]. International Journal of Applied Biology and Pharmaceutical Technology. 2013; 4:41-53.

8. Reddy VG, Jayalakshmi V, Sreenivas T. Genetic divergence studies in pigeonpea inbreds. Electronic Journal of Plant Breeding. 2015; 6(2):515-520.

9. Saxena KB, Sultana R. Quality nutrition through pigeonpea a review. Jouranal of health. 2010; 2(11):1335-1344.

10. Singh MN, Awasthi SK, Singh RS. Genetic divergence in pigeonpea. Journal of Food Legumes. 2010; 23(1):82-83. 